\title{
THE GEORGE HAMMELL COOK COLLECTION
}

\author{
BY JEAN WILSON SIDAR
}

Ms. Sidar, Assistant Secretary of Rutgers University and a graduate student in history at the university, is at work on a biography of Cook with

a grant from the New Jersey Agricultural Society

$7 \mathrm{HE}$ recent decision of the Board of Governors of Rutgers University to establish a new undergraduate college to be called "Cook College" has brought the Rutgers scientist George Hammell Cook into new prominence. But however important Cook College may become, it will probably not loom as large in this century as did Cook himself in the New Jersey of the nineteenth century. State geologist, first Director of the New Jersey Agricultural Experiment Station, Vice President of Rutgers, member of the National Academy of Science, Vice President of Section E (Geology and Geography) of the American Association for the Advancement of Science, founder of the New Jersey State Board of Agriculture, and a Vice President of the National Agricultural Society-these titles represent but a part of his leadership and involvement in the educational, geological, agricultural, and environmental movements of the period.

Fortunately for historians, Dr. Cook was a systematic and wellorganized man and, in the manner of his century, a very saving man. He and later his wife, Mary Halsey Thomas Cook, and his daughters, Emma and Anne, saved almost all his books, journals, papers, letters, and notebooks. When Anne, who died in I937, gave the collection to the Rutgers Library there were forty-nine large file boxes of letters and notebooks. Some of these papers were used by Carl R. Woodward and Ingrid Nelson Waller in writing New Jersey's Agricultural Experiment Station: I880-I930. But when the New Jersey Agricultural Society presented a grant from Charles A. Collins, Vice President of the New Jersey State Board of Agriculture, for the preparation of a biography of George Cook, most of the letters were tied up in red tape as Cook had left them. There are at a rough estimate about 20,000 letters and I 24 notebooks. Although their arrangement is still not completed, most of the letters have been filed chronologically and to a lesser extent by subject 


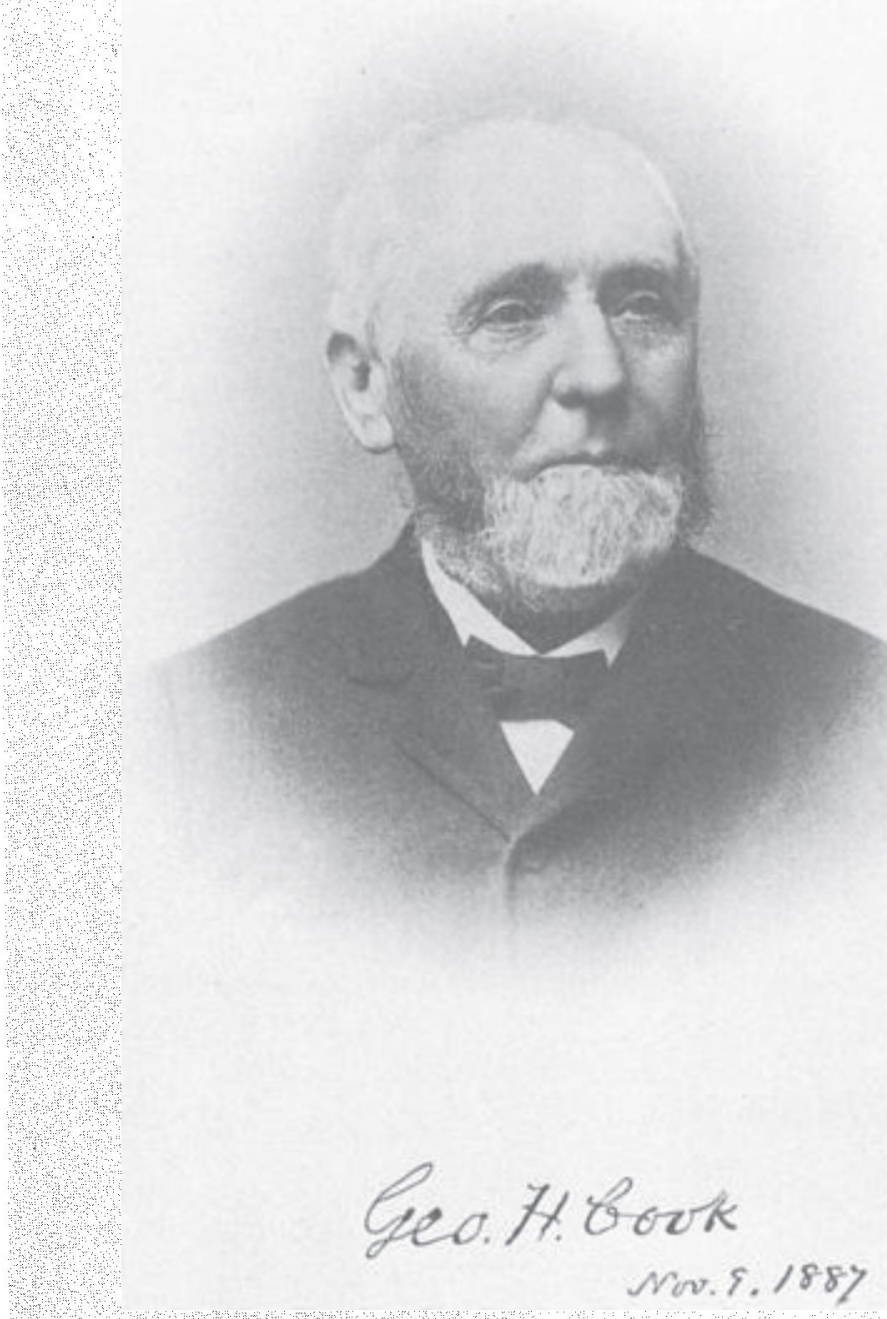


matter. Written between 1836 and 1890 , they throw light on the development of geology and agriculture, the growth of state and federal support for agricultural colleges, experiment stations, and geological surveys; problems of drainage and water supply in New Jersey, and a multitude of other subjects. They also provide a source of information about the customs, pleasures, worries, and habits of their writers.

The earliest letters are a rich source of information on life in the nineteenth century. These personal letters from Cook's family and friends tell of ploughing and planting on the family farm in Hanover, New Jersey; of the pleasures of snowy sleigh rides to Chatham; of malaria, consumption, "tisic," and the other illnesses that beset them; of the twice-a-Sunday sermons: and of other concerns of their daily lives. David Cook, George's brother, wrote in his letter of November I5, I 840:

"Mr. W. left last week . . . he gave good satisfaction as teacher but some thought that $\$ 20$ per month [was] too much with board and so they voted him $\$ 20$ a quarter. He accepted if they would send scholars enough to make $\$ 20$ per month. They agreed to that and before the quarter was half out [he] had many more than [he wanted] and more acoming every day, so that he got sick from too much confinement. ... The debating society has met once a month and has a lecture from different persons. Only one of the members has attempted to lecture. That was D. Ball. A part of his discourse was tolerable but his history of love and affection was intolerable for publick discusion (sic).... We have a large singing school-about 50 male members at $\$$ I each, spectators I $2 \frac{1}{2}$ cents each, females gratis. Philip Ward of Orange is the teacher. F. F. Boudinot has been quite regular, the first time he came he was so drunk that he could not stand still and had not $\mathrm{I} 2 \mathrm{~T} / 2 \phi$ to get in the school. ..."

Very few of the letters written during the period of the Civil War have anything at all to say about the war. An exception is a letter written by another brother, Henry, revealing a wry sense of humor: 


\begin{abstract}
"... There is not much talked about here but the war. It has produced some patriotic excitement which finds vent in tall poles, large flags, neighborhood military companies, and a great deal of talking. There have been some very nice poles raised in the vicinity, one in Columbia, one at East Madison, and another at Whippany Bridge. These are all considerable (sic) over IOO feet high. Besides these there are several others from 60 to 80 feet. At most of these pole raisings $\mathrm{Mr}$. Johnson gives a patriotic speech. He has also given us a patriotic sermon for the times. Aaron G. Baldwin is frequently a speaker at these pole raisings-quite eloquent too. $\mathrm{He}$ is also captain of a small military company in this place."
\end{abstract}

Henry's letter was written in June of I $86 \mathrm{I}$ when George had been at Rutgers College as Professor of Chemistry and Natural Science for seven years. The following year saw the passage of the Morrill Act establishing land-grant colleges. Cook was at the forefront of the Rutgers effort to become the land-grant college of New Jersey. An effort was also made by Princeton professors as the following letter indicates:

\title{
Professor George H. Cook My Dear Sir:
}$$
\text { February I I, I } 864
$$

In accordance with your request I have copied the two letters which you left in the office a few days ago ... I hear nothing much considering the College. The "Considerations" are before the members. Princeton has published two already and I see their Professors around a good deal. They will have their chance before the Committee next week. ... .

\section{Very truly yours,}

Garrett D. W. Vroom ${ }^{2}$

1 "Considerations in Regard to the Disposal to Be Made by the Legislature of New Jersey of the Lands Granted by Congress for Encouraging Education in Agriculture and the Mechanic Art," a pamphlet written to support the Rutgers cause by Cook and David Murray, professor of mathematics. No copy of the original has been found.

${ }^{2}$ Son of ex-Governor and Rutgers supporter, Peter D. Vroom. 
The friends of Rutgers proved among the legislators to be more convincing than those of Princeton and Rutgers became New Jersey's land-grant college. This led eventually to Cook's appointment as Professor of Agriculture and Geology and in I 880 as Director of the New Jersey Agricultural Experiment Station. Many of his letters after I 862 center on the problems of agricultural education and the development of agricultural science. But Cook also received many letters from the farmers of New Jersey seeking help with their individual problems. The following letter is an example:

\author{
5 mo. 23, I 876 \\ Merchantville, N.J. \\ Professor George H. Cook \\ Dear Sir:
}

In view of the depredations of the Colorado Potato Beetle upon tomatoes, egg plants, peppers \&c. I should be obliged if you would inform me whether the application of Paris Green to such plants in the blossom state would be likely to poison the fruit. The early setting of tomatoes are in bloom and many of our truckers and planters contemplate applying the green, but are uncertain what effect it may have upon the fruit; it is very certain that unless this remedy can be used with safety, that the early crop of the above mentioned fruits must prove a failure ..."

Very truly yours,

E. Burrough

Of all the correspondents on agricultural questions-and some of them were very eminent men both in this country and in Europenone is of more interest to those with some knowledge of the history of Rutgers than James Neilson. Neilson was a generous contributor to the college. He gave most of the land that is now Neilson Campus and left his beautiful home, Woodlawn, which now houses the Eagleton Institute of Politics, to the trustees of Rutgers. An enthusiastic and knowledgeable farmer who served on the Board of Managers of the Experiment Station from I 880 until his death in 1937, Neilson had traveled to Europe in Cook's company in 1870 . The party had visited agricultural schools and experiment stations throughout 
Europe. Two years later he visited Europe again. and wrote from London:

July 22,1872

... We reached Liverpool on Tuesday last and ran down to Cardiff, South Wales, the next day by which we were in time for the last two days of the "show" of the Royal Agricultural Society. It was by far the finest thing of the kind I have ever seen. The entries of horses, cattle, sheep, \&c and steam and other agricultural machinery and tools was fine. ... I was tempted into ordering from Ransom \& Sims a plow with a subsoil attachment, and think of getting a double plow too. Their plowman, who goes about to contend for prizes likes a light double plow of theirs very much; he says he can easily do two days work in one with it with an ordinary pair of horses. I think it will be a grand thing for working over ground a second and third time for roots and cabbage, \&c. The farmers here like the chain harrow very much, both for spreading manure evenly, and for scraping together couch grass. The steel harrow jointed in every direction and with long teeth pointing forward is a splendid implement. I am convinced it sticks close to the ground doing double the work of our stiff wooden ones with only one or two joints, and the bent teeth clear out the couch grass, bringing it to the surface, after which the chain harrow gathers it and all is removed by women and children by hand. ..."

Even before he became a leader in agriculture Cook had been involved in the geological survey of New Jersey. From the time of his enrollment in the Rensselaer Institute (as it was then called) in I 839, Cook received letters on many scientific matters. As his work in geology increased the letters he received reflected this. They bear the signatures of men prominent in scientific circles a hundred and more years ago: Amos Eaton, Joseph Leidy, Charles Abbott, Timothy Conrad, James Dwight Dana, Joseph Henry, and James Hall are among the best known. In some cases these men wrote about 
details of arrangements for meetings, word of appreciation for the latest annual report of the geological survey, or similar mundane matters. Frequently, however, they wrote about problems they were working on. James Hall, paleontologist and most prominent member of the famous New York Geological Survey team, was one of Cook's most constant correspondents. Hall's letters begin in 1842 when Cook was head of the Rensselaer Institute and continue through the I 880's. Hall was a graduate of Rensselaer and served on its faculty at various times. He became the foremost paleontologist in the United States and has been labeled "the father of American stratigraphy." A man of great vigor and determination he carried on at his own expense when the New York State legislature failed to appropriate money to continue the survey in the 1850's. Eventually he became so possessive of his field that he made many enemies. However, he remained fast friends with Cook. During the I 880 's Hall and Cook were both members of the American Committee of the International Congress of Geologists. One of the problems the body grappled with was the attempt to find a logical relationship between the geological formations of Europe and those of the United States. In connection with this, Hall wrote:

February 17, 1887

I ... wish to present a comparison of the cretaceous formation in New Jersey with that in the southwest. Have you anything to add to your published section? If you have please give me the information-or if you will —on a sheet of paper mark your successive beds and in the lines opposite give me the names of as many of the fossils as you can \& also of any series occurring in two or more beds. I wish to get information particularly of the lowest beds you have of any kind in the state that is of cretaceous age. And the character of the fossils-Of course I have the labelled collections here which will aid me much but of the cephalopods or ammonites, bacelites, etc. I wish to know more of their range, occurrences, etc.

The work of the American committee did not always go smoothly; later that year Hall wrote: 
Professor George H. Cook

\section{October I 4, I 887}

Dear Sir:

Professor Hitchcock has written to propose that we have a meeting of the International Geological Committee on December 27 th. . . . It is proposed that the meeting occupy one evening. In view of what occurred in New York I think one evening will accomplish very little, and we have got into such a snarl that I think there should first come a quiet discussion among the older members of the committee before any general meeting. The temper and dispositions manifested do not please me, but while I remain on the committee I am at the service of its members. ...

Another member of the committee was Dr. Othniel C. Marsh, professor of vertebrate paleontology at Yale who wrote on more technical matters:

Professor George H. Cook

December 20, I 887

Dear Sir:

Your note and the accompanying proof [of Cook's report on the Triassic] came during my absence in New York, and I wish now a word to acknowledge its receipt. ... I have some important evidence about the relations of the Jura and Trias both in the West and on the Atlantic Coast that the Report sent does not touch, and I shall be glad to give you the new points, either by letter, or verbally when you come here. ...

A large number of letters on geology in the Cook collection were written by John Smock, Cook's assistant on the New Jersey survey, who later became professor of mining and metallurgy at Rutgers and then assistant director of the New York State Museum. In I875 Smock and two assistants were in the field in the northern part of New Jersey collecting information on the terrain and rock specimens to be included in the New Jersey exhibit at the Philadelphia Centennial Exposition in I876. He wrote from Washington, New Jersey: 
Dear Professor Cook:

August IO, I 875

Our work of collecting is being prosecuted about as fast as our horse will enable us to go. We have been at several mines west and south of this. ... Have collected many typical rocks. The distance between localities takes much time. Yesterday we were at Oxford Furnace. I had a long talk with Mr. Selden Scranton concerning the mode of collecting iron ores and with Charles Scranton about localities and went thence to Pequest mines and eastward across Pohatcong and Musconetcong Mountains to Port Murray and back here. ... Today and tomorrow we shall be along the Delaware and on Scott's and Marble Mountains. Then to north on Jenny Jump and across to Hackettstown by Saturday....

Our horse is too light for these hills. We walk much of the way.... I fear he may not hold out. And I hate to see so nice a horse worn out by this kind of work. What we need is a stout draught horse that cannot be hurt. ... It seems to me that it would be economy to change and I therefore strongly urge it. ... .

Very truly yours,

John Smock

Several days later Smock wrote from Hackettstown.

Dear Professor Cook:

August 24, I875

We are now making progress with a team instead of a jaded out horse to our wagon. ... Y Yesterday we were on Schooley's Mountain south of the springs. Today we are going to Warrenville ... you can address us there until Friday night. Then at Newton. From there I propose moving to Ogdensburgh.

Dear Dr. Cook:

Ogdensburgh, September I 5, I 875

We are again at the zinc mines. We stopped at Lafayette to see the slate quarry now being worked. 
I called on Mr. Bunnell and on Dr. F. Smith in Newton. The doctor says he cannot find the old franklinite iron. He gave me a piece of jeffersonite. I left work with Mr. Bunnell to care for some fossils promised from the limestone quarries of Montague and Walpack.

I can find no great variation in the strike of the palaeozoic rocks-such as is common in the gneiss of these Highlands. In the former the strike is almost always N.E. \& S.W. whereas here we find N.S. and E.W. strikes. This is, I think, a marked difference in the structure of North Jersey. ..."

Cook's agricultural and geological responsibilities led him into many diverse activities. A listing of them makes for dull reading, but it may indicate the usefulness of the Cook collection for the historian of the movements and organizations, in which he was involved. In I 886 Cook was named Director of the New Jersey State Weather Service. He became Surveyor General of the Board of General Proprietors of the Eastern Division of New Jersey in I 883. He was one of three Drainage Commissioners of New Jersey, a member of the executive committee to organize the Association of Land Grant Colleges and a Water Commissioner in the City of New Brunswick. In addition he was an elder in the Second Reformed Church of New Brunswick and Superintendent of the Sunday School for a number of years. This list in itself may give some idea of the character of George Cook. He was conscientious, hard-working, and possessed of a seldom-equalled ability to work with people. The Cook Collection is full of letters that reinforce these conclusions. They add also a sense of the kindness and warmth of the man as the following examples will show:

Cuba, June 30 , I 863

Dr. G. H. Cook

Dear Dr. Cook:

... I am busy combating disease, ignorance, and muddy roads during the rainy season. Every day, My dear Dr., the lessons you taught us prove more valuable, to me at least, and if it will in any degree com- 
pensate for the pains you took in teaching us rest assured of the fact in one case at least. ...

Sincerely yours

Dr. J. B. Dod

Massachusetts Agricultural College

April ro, I 874

Professor George H. Cook

Rutgers College

My dear Friend:

Thanks for your interesting Reports as Professor, Secretary, and Geologist. I think I can now understand that you have not wasted many hours in idleness during the past year. May your strength continue equal to your industry and laudable ambition. How much faster the world would get on if all would do their very best. But do not overwork, Remember much remains to be done.

Sincerely yours,

W. S. Clark

President

Dear Uncle,

Antioch, California

January I 3, I 872

... You can drop some of your work-can't you? I do not like you to be so driven. ... The picture is our boy-he is now in his tenth month.... If he lives and wants to go and can go to College will you do him the favor you did me and let him live with you? I could desire but few things for him more than this....

Yours sincerely

Edward Thomas

New Hampshire

I 887

Dear Dr. Cook,

... If anything occurs to you which I can do this summer for the college, I shall be glad to have you 
suggest it. I am at work easily on next year's lectures, now.

To Dr. Doolittle, Dr. Meyer, Prof. Van Dyck, Dr. Austin, Dr. Scott, and Prof Wilbur, please give my cordial regards when they drop in (as we are all so fond of doing) at your office, to exchange greetings with you.

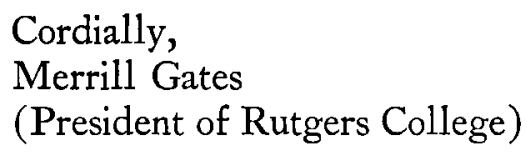

Cordially, Merrill Gates

(President of Rutgers College)

All who have spent any time reading the letters and notebooks in the Cook Collection (or who have heard about him from those who have) come away fascinated and impressed. On the evidence of the collection-as well as on the more tangible evidence of Cook's role as Director of the New Jersey Agricultural Experiment Station, it becomes clear that the Board of Governors made an unassailable decision when they chose to name the College of Agriculture and Environmental Science, "Cook College." 